\title{
DESAFIOS E METAS NO ENSINO DA MICROBIOLOGIA
}

\author{
José Augusto A. Pereira \\ Professor Associado da Universidade do Estado do Rio de Janeiro \\ Departamento de Microbiologia e Imunologia - FCM/UERJ \\ 凶josepuerj@bol.com.br
}

O Ensino de Microbiologia se dá em uma gama muito diversa de contextos na Educação. Devemos reconhecer que, no dia a dia de todos nós, as questões dos micróbios estão patentemente presentes. Precisamos abordá-la na Educação formal e, também, na informal. Desde a infância precisamos nos apossar de informações, práticas, valores, estabelecer atitudes importantes para nossa vida individual e coletiva. No ensino fundamental e médio estão contemplados temas que vão progressivamente constituindo esta necessária Educação. Desde aquele nível, está presente a questão da necessidade da Educação no sentido da formação do indivíduo autônomo, criativo, crítico, cidadão, competente para a vida, em geral. A abordagem da Microbiologia em vários momentos do Ensino deve ser de busca de uma integralidade. Nossa visão, criticamente na atualidade, requer um reconhecimento da Humanidade como inexoravelmente constituinte de um sistema planetário que inclui as complexíssimas interações com os micróbios, estruturando o "funcionamento" do Mundo. É importante enfatizar que os microrganismos são parte de metáfora ou analogia do mundo sistêmico, pois sem eles não há vida "superior": plantas, animais, decomposição de cadáveres, em geral, digestão de diversos nutrientes nos seres vivos. Isto favorece o trabalho com a dimensão afetivo-emocional da inteligência e promove o reconhecimento de responsabilidade com a Vida, em geral. Nossa competência de procedimentos, criticismo, entendimento, adequação nos procedimentos de higiene individual e coletiva, própria e no cuidado de outro (paciente, criança, idoso, indivíduos dependentes, em geral), da produção de alimentos, da agricultura e pecuária, do saneamento, da prevenção, diagnóstico e tratamento de doenças infecciosas, entre outros, exige os conhecimentos da Microbiologia. De fato, ao longo da História, estes conhecimentos apareceram (e ainda aparecem) como Saberes, ocorrendo uma estruturação científica, na segunda metade do século XIX. Cabe reconhecer a necessária abordagem social, psicológica desses contextos de vida. Porque aos objetos "puros" da ciência (bactéria, vírus, infecção, transmissão, contaminação, entre outros) correspondem imagens, representações, concepções que em alta medida determinam as atitudes e comportamentos humanos, também, nesse particular da questão dos micróbios. 
Podemos considerar, então, diferentes âmbitos de Ensino, na sua racionalidade e intencionalidade. Uma condição mais geral de conhecimento necessária a todos no sentido de condição para o viver. Adicionalmente, devemos considerar o Ensino de Microbiologia na formação básica para profissionais de áreas técnicas e de graduações em área da Saúde (Odontologia, Nutrição, Biologia, Medicina Humana, Medicina Veterinária, Ciências Biológicas, Farmácia, Biomedicina, entre outros). Mais intensivamente se dá o Ensino para os profissionais que se especializam como técnicos, bacharéis, na pós-graduação lato sensu ou stricto sensu (mestrado, doutorado). Em nenhum destes âmbitos, penso eu, podemos perder a atenção e a ênfase na intencionalidade para as questões gerais da Educação dos indivíduos.

É necessária a promoção de atitudes de responsabilidade, tendo-se em conta as questões dos vários riscos associados aos "objetos" de estudo, em si, e dos procedimentos de "manipulação" destes. A esta exigência corresponde uma imperiosa necessidade de conhecimento para prever, controlar, prevenir danos e malefícios próximos ou distantes (no tempo e/ou no espaço).

No passado, era comum se organizar um programa de Microbiologia dirigido pela abordagem por agentes microbianos específicos. Os diferentes tipos de infecções eram, para cada um destes, descritos. Entretanto nas últimas décadas, nas áreas de Saúde, tem-se recorrido à abordagem dos diferentes microrganismos, a partir das infecções causadas por estes, discutidas para diferentes sistemas (tratos). Infecções do trato respiratório (superior e inferior), urinária (alta e baixa), genital, pele, sangue, sistema nervoso central. Desta forma, segue-se uma visão clínica da Microbiologia, com a primazia para as manifestações das infecções. Procura-se, então, explorar algo como um diagnóstico diferencial (clínicolaboratorial), no qual diferentes possibilidades são discutidas por suas características mais marcantes. Dada a grande variedade de microrganismos capazes de causar infecções humanas cabe, então, discutir num Ensino, digamos fundamental, de Microbiologia valendo-nos de uma visão de conjunto, constituindo-se, assim, "grupos" de microrganismos, considerando aspectos gerais de estruturas e funções.

Os recursos da Biologia Molecular, desde o último quartil do século passado, têm se constituído em ferramentas de inestimável importância para a abordagem microbiológica na Saúde Pública. Em várias tarefas neste âmbito, estes recursos técnicos podem ser valiosos, sem excluir os recursos convencionais (fenotípicos), mas promovendo-os, trazendo 
incrementos nos graus de sensibilidade e especificidade de procedimentos na detecção, como exemplos, de agentes microbianos, toxinas e efetores imunológicos. Adicionalmente, a aplicação de tais métodos permite a identificação acurada e a detecção de genes específicos relacionados a propriedades de resistência a vários tipos de agentes, incluindo-se antimicrobianos, e aqueles determinantes relacionados à patogenicidade e á virulência de microrganismos. Devemos preparar condições para que a(o)s acadêmica(o)s entendam a utilização de instrumentos que, em condições de maior recurso, podem permitir (não totalmente!) a realização de múltiplos testes de identificação em condições que denominamos de "automação".

Podemos considerar grosso modo três situações referentes à causação de infecções humanas: i) microrganismos desprovidos dessa competência (de utilização de nossos organismos como meio para sua multiplicação), p.ex.: bactérias fotossintetizadoras, litoautotróficas ..., ii) microrganismos (muito) competentes em se estabelecer no nosso organismo causando infecção, transpondo as barreiras impostas por sistema imune íntegro (patógenos "clássicos") e iii) microrganismos anfibiontes ("vida dupla", patogenicidade e constituição de microbiotas): incompetentes, em geral, para causar infecção em condições de integridade de defesa do hospedeiro, podendo, participar de microbiotas normalmente associadas a diferentes sítios anatômicos (outros, presentes nos ambientes "naturais", em geral), mas capazes de causar infecção em imunodeficientes.

Um avanço importantíssimo para a compreensão da atividade do Sistema Imunológico contra agentes infecciosos se deu, a partir da década de 60 do século passado, quando se constatou que, além de uma imunidade "natural", atuam dois grandes grupos de efetores das defesas do organismo (subdivisíveis, também): a imunidade dada pelas diferentes classes de anticorpos (humoral) e a imunidade celular que se dá pela participação de linfócitos $\mathrm{T}$ (celular) efetuadores. De maneira bem prática podemos dizer que, em geral, pensa-se na proteção como sendo devido a anticorpos. Mas para muitos microrganismos relevantes em infecções humanas (e de outros animais) é fundamental a participação da imunidade celular (dependente de linfócitos, e seus produtos, mobilizando, de forma muito especial, macrófagos ativados, como denominamos aqueles diferenciados após ação de produtos especializados de linfócitos envolvidos no processo de defesa). Também, conhecendo setores da imunidade comprometidos, podemos inferir patógenos mais prováveis. É algo de grande importância no Ensino da Microbiologia atingir-se essa compreensão a partir da interação dos conhecimentos 
de Microbiologia e Imunologia. Apesar de dispormos desse conhecimento fundamental dos dois "braços da imunidade", a apropriação dos mesmos ainda é uma situação um tanto distante para ser atingida. Creio que devemos investir nesse muito importante objetivo didático.

A emergência de agentes microbianos de gravíssimas infecções e a sua rapidez de disseminação planetária indicam-nos o caráter "sistêmico" da dinâmica dos microrganismos em âmbito global. Devemos discutir, nos contextos de Ensino da Microbiologia, os fluxos de genes de resistência aos antimicrobianos e de virulência nos trazem o reconhecimento de que é acidental e problemática para o homem, mas é natural para os microrganismos.

A disciplinaridade "fechada" se torna insustentável diante de tal monta de interações relevantes de fenômenos de várias ordens e dimensões. A própria contradição aprofundada da corrida contra os problemas, para os quais a produção de soluções tecnológicas poderia ser solução (atenuando ou minimizando impasses de ordens político-sociais com o emprego de antimicrobianos, vacinas, etc.) são efetivamente comprometidos na vigência de péssimas condições de nutrição, saneamento, informação cabível e cuidados básicos de saúde. Os esforços de solução da questão da resistência aos antimicrobianos de agentes infecciosos, por exemplo, estão, cada vez mais, dependentes de abordagens diagnósticas e de intervenções no âmbito das ciências humanas e sociais.

Os micróbios não "criam" especialmente, ou de forma dirigida, problemas para o homem pela sua capacidade de transmissão ou pelas mutações e transferência de genes de resistência, de virulência ou genes codificando enzimas relacionadas a atividades metabólicas específicas. Ao contrário, são essencialmente produtores de "novidades" e de "soluções" para eventual transposição de obstáculos para as suas sobrevivências, há muitos e muitos milhões de anos, muito antes do aparecimento do homem no planeta. Um pensador, prêmio Nobel, François Jacob, dizia: "O sonho de uma bactéria... é o de se dividir em duas". Isso me parece ser uma expressão de atitude "aberta" para um conhecimento mais adequado dos micróbios, inclusive para quando precisamos destruí-los. Entretanto, o próprio poder destrutivo dos microrganismos utilizados, infelizmente, pelo homem como armas biológicas, permite prever consequências desastrosas intencionais. Não é exagero que prevenção destes riscos da insânia humana podem depender do caráter educativo no ensino da Microbiologia. 